\title{
Assessment of the hormonal levels in different management strategies for women with cervical insufficiency and a history of anovulatory infertility
}

\author{
L. V. Pakharenko®A,C,D,E,F, O. M. Perkhulyn $\mathbb{D}^{\mathrm{B}, \mathrm{C}, \mathrm{D}}$
}

Ivano-Frankivsk National Medical University, Ukraine

A - research concept and design; B - collection and/or assembly of data; C - data analysis and interpretation; D - writing the article;

$\mathrm{E}$ - critical revision of the article; $\mathrm{F}$ - final approval of the article

Key words:

cervical

insufficiency,

treatment,

cervical cerclage

cervical pessary,

progesterone.

\section{Zaporozhye}

medical journal

2021; 23 (1), 98-104

*E-mail:

ludapak@ukr.net
Cervical insufficiency $(\mathrm{Cl})$ is one of the causes of preterm birth. The rate of $\mathrm{Cl}$ is higher in women after in vitro fertilization treatment for infertility compared to the general population.

The aim. To assess the hormonal level in women with $\mathrm{Cl}$ and a history of anovulatory infertility in the second and third trimesters of pregnancy in different management strategies for $\mathrm{Cl}$.

Materials and methods. 60 pregnant women with $\mathrm{Cl}$ who conceived through in vitro fertilization treatment for anovulatory infertility were divided into two groups: in the I group (30 women), $\mathrm{Cl}$ was corrected only with cervical cerclage / pessary in the II trimester of pregnancy, in the II group (30 persons), cervical cerclage / pessary was combined with vaginal progesterone $200 \mathrm{mg}$ ones a day until 34 full weeks of gestation. 30 pregnant women without $\mathrm{Cl}$ or infertility with the physiological course of pregnancy were controls. The concentrations of estradiol, progesterone, placental lactogen, prolactin and cortisol were determined in the terms of 19-22 and 30-32 weeks of gestation in the maternal blood serum.

Results. In the patients with $\mathrm{Cl}$ at 19-22 gestational weeks, the estradiol and placental lactogen concentrations were slightly lower in the I and II groups than those in the control women, the level of progesterone was less in the I group by $13.44 \%$, in the II group - by $17.30 \%(P<0.05)$ compared to the controls; the levels of prolactin and cortisol in the I and II groups were increased significantly $(P<0.001)$. At 30-32 gestational weeks, the levels of estradiol $(P<0.05)$, progesterone (a decrease of $23.10 \%$, $P<0.001$ ) and placental lactogen (a decrease of $10.74 \%, P<0.05$ ) were significantly less as compared to the physiological ranges, while these parameters in the II group patients were on the lower limit of normal. In the I group, the concentrations of prolactin and cortisol were higher by $41.70 \%(P<0.001)$ and $27.36 \%(P<0.001)$, respectively, than the controls, in the II group - only by $24.10 \%(P<0.05)$ and $13.70 \%(P<0.05)$, respectively.

Conclusions. In the women with cervical insufficiency after in vitro fertilization treatment for anovulatory infertility, the levels of estradiol, progesterone and placental lactogen are not significantly different from physiological indices, but the prolactin and cortisol concentrations are much higher. Adjunctive vaginal progesterone treatment to cervical cerclage/pessary in the third trimester of pregnancy promotes the normalization of progesterone, estradiol and placental lactogen levels, the decrease in prolactin and cortisol indices at 30-32 gestational weeks compared to the women with cervical cerclage/pessary alone.
Киючові слова: істміко-цервікальна недостатність, мікування, цервікальний серкляж, акушерський песарій, прогестерон.

Запорізький медичний журнал 2021. T. 23, № 1(124). C. $98-104$

\section{Оцінювання гормонального фону при різних методах мікування істміко-цервікальної недостатності в жінок з ановуляторним безпліддям в анамнезі}

\section{А. В. Пахаренко, О. М. Перхулин}

Істміко-цервікальна недостатність (ІЦН) - одна з причин передчасних пологів. Частота ІЦН вища в жінок після лікування безпліддя за допомогою екстракорпорального запліднення порівняно з показником у популяції загалом.

Мета роботи - оцінити рівень гормонів у жінок з істміко-цервікальною недостатністю й ановуляторним безпліддям в анамнезі у другому та третьому триместрах вагітності при різній тактиці ведення ІЦН.

Матеріали та методи. 60 вагітних із ІЦН, в яких вагітність настала після лікування ановуляторного безпліддя за допомогою екстракорпорального запліднення, поділили на дві групи: в І групі (30 пацієнток) корекцію ІЦН виконали тільки накладенням цервікального серкляжа або встановленням акушерського песарія у II триместрі вагітності; у ІІ групі (30 осіб), крім цервікального серкляжа/акушерського песарія, додатково призначали вагінальний прогестерон по 200 мг один раз на добу до 34 повних тижнів вагітності. 30 вагітних без ЦЦН і безпліддя з фізіологічним перебігом вагітності включили в контрольну групу. Концентрації естрадіолу, прогестерону, плацентарного лактогену, пролактину та кортизолу визначали в 19-22 і 30-32 тижні гестації в сироватці крові матері.

Результати. У 19-22 тижні вагітності в пацієнтів з ІЦН концентрації естрадіолу, плацентарного лактогену в I I II групах дещо нижчі, ніж у жінок контрольної групи, рівень прогестерону нижчий в I групі на 13,44 \%, у II групі - на 17,30 \% (p< 0,05) порівняно з контролем; концентрація пролактину й кортизолу в I і II групах істотно збільшена ( $<$ < 0,001). На 30-32 тижні вагітності рівні естрадіолу ( $<<0,05)$, прогестерону (зниження на 23,10 \%, $p<0,001)$ і плацентарного лактогену (зниження на 10,74 \%, p < 0,05) значущо нижчі порівняно з фізіологічними параметрами, а в пацієнтів II групи ці величини були на нижньому рівні значень норми. У I групі концентрації пролактину та кортизолу вищі на 41,70\% $(p<0,001)$ і $27,36 \%$ $(p<0,001)$ відповідно щодо норми, у II групі - тільки на 24,10\% $(p<0,05)$ i 13,70 \% ( $p<0,05)$. 
Висновки. У жінок з істміко-цервікальної недостатністю після лікування ановуляторного безпліддя шляхом екстракорпорального запліднення рівні естрадіолу, прогестерону та плацентарного лактогену істотно не відрізняються від фізіологічних показників, але концентрації пролактину й кортизолу вірогідно вищі. Додаткове використання вагінального прогестерону у III триместрі вагітності разом із накладанням цервікального серкляжу/акушерського песарію сприяє нормалізації кількості прогестерону, естрадіолу та плацентарного лактогену, зменшенню показників пролактину й кортизолу в 30-32 тижні гестації порівняно з жінками, в яких тільки встановлено цервікальний серкляж/песарій.

\section{Оценка гормонального фона при различных методах мечения истмико-цервикальной недостаточности у женщин с ановуляторным бесплодием в анамнезе}

\section{А. В. Пахаренко, О. М. Перхулин}

Истмико-цервикальная недостаточность (ИЦН) - одна из причин преждевременных родов. Частота ИЦН выше у женщин после лечения бесплодия с помощью экстракорпорального оплодотворения по сравнению с показателем в общей популяции.

Цель работы - оценить уровень гормонов у женщин с истмико-цервикальной недостаточностью и ановуляторным бесплодием в анамнезе во втором и третьем триместрах беременности при различной тактике ведения истмико-цервикальной недостаточности.

Материалы и методы. 60 женщин с ИЦН, у которых беременность наступила после лечения ановуляторного бесплодия с помощью экстракорпорального оплодотворения, разделены на две группы: в I группе (30 пациенток) коррекция ИЦН проведена только наложением цервикального серкляжа или установкой акушерского пессария во II триместре беременности; во II группе (30 человек) помимо цервикального серкляжа/акушерского пессария дополнительно назначали вагинальный прогестерон по 200 мг один раз в день до 34 полных недель беременности. 30 беременных без ИЦН и бесплодия с физиологическим течением беременности составили контрольную группу. Концентрации эстрадиола, прогестерона, плацентарного лактогена, пролактина и кортизола определяли в 19-22 и 30-32 недели гестации в сыворотке крови матери.

Результаты. В 19-22 недели беременности у пациентов с ИЦН концентрации эстрадиола, плацентарного лактогена в I и II группах несколько ниже, чем у женщин контрольной группы, уровень прогестерона ниже в I группе на 13,44 \%, во II группе - на 17,30 \% ( $<$ < 0,05) по сравнению с контролем; содержание пролактина и кортизола в I и II группах значительно увеличено ( $p<0,001)$. На 30-32 неделе беременности уровни эстрадиола $(p<0,05)$, прогестерона (снижение на 23,10\%, p < 0,001) и плацентарного лактогена (снижение на 10,74 \%, p < 0,05) значительно ниже по сравнению с физиологическими параметрами, а у пациентов II группы эти величины были на нижнем уровне значений нормы. В I группе концентрации пролактина и кортизола выше на 41,70 \% ( $<<0,001)$ и $27,36 \%(p<0,001)$ соответственно по сравнению с нормой, во II группе - только на 24,10 \% ( $<<0,05)$ и 13,70 \% ( $<<0,05)$.

Выводы. У женщин с истмико-цервикальной недостаточностью после лечения ановуляторного бесплодия путем экстракорпорального оплодотворения уровни эстрадиола, прогестерона и плацентарного лактогена существенно не отличаются от фризиологических показателей, но концентрации пролактина и кортизола значительно выше. Дополнительное использование влагалищного прогестерона в III триместре беременности вместе с наложением цервикального серкляжа/ акушерского пессария способствует нормализации количества прогестерона, эстрадиола и плацентарного лактогена, уменьшению показателей пролактина и кортизола в 30-32 недели гестации по сравнению с женщинами, имеющими только цервикальный серкляж/пессарий.

Preterm labor and pregnancy loss remain major challenges for practical obstetrics. Among the most common risk factors are statuses following a spontaneous preterm delivery, medically indicated preterm birth or conization of the cervix; an interpregnancy interval of less than 12 months, young maternal age under 18 years old, bacterial vaginosis, asymptomatic bacteriuria, vaginal bleeding during gestation, etc. [1]. Also, the main reasons of the pregnancy loss include cervical insufficiency $(\mathrm{Cl})$, large uterine fibroid, threatened miscarriage related to chorionic or placental abruption, a prior history of multiple pregnancy loss, injuries to the uterine cervix [2]. Besides, it was established that the risk of preterm birth even in singleton gestation is associated with additional reproductive technology, particularly, with in vitro fertilization (IVF) and intracytoplasmic sperm injection compared with spontaneously conceived pregnancy [3].

$\mathrm{Cl}$ is a known risk factor for preterm labor. Its frequency is about $1 \%$ of all pregnancies [4], but its prevalence is greater in the women after in vitro fertilization (IVF) reaching 9.7-14.4\% [5]. Usually, it is diagnosed in the second trimester of pregnancy and associated with cervical trauma during the previous labor, operations, or cervical manipulations [6]. Currently, the concept of a short cervix is commonly used in the obstetrical practice. It is generally defined as the uterine cervical length less than $25 \mathrm{~mm}$ by transvaginal ultrasound [7]. Ordinarily, the short cervix may lead to the preterm birth. The management strategy for pregnant women with $\mathrm{Cl}$ has remained constant for many years. Typically, this pathology is corrected with cervical cerclage (prophylactic or rescue) or cervical pessary [8-10]. In resent years, the administration of vaginal progesterone alone or in a combination with cervical cerclage/pessary has been discussed in the treatment for women with short cervix and $\mathrm{Cl}$ at low or high risk of preterm birth $[7,11]$.

\section{Aim}

To assess the hormonal level in the women with $\mathrm{Cl}$ and a history of anovulatory infertility in the second and third trimesters of pregnancy in different management strategies for $\mathrm{Cl}$.

\section{Materials and methods}

The study included 60 pregnant women with $\mathrm{Cl}$ who conceived after the treatment for anovulatory infertility through
Ключевые слова:

истмикоцервикальная неАостаточность, мечение, цервикальный серкляж, акушерский пессарий, прогестерон.

Запорожский медицинский журнал. 2021. T. 23, № 1(124). C. $98-104$ 
Table 1. Reproductive anamnesis of the previous pregnancies in the examined patients (abs., \%)

\begin{tabular}{|l|l|l|l|} 
Reproductive data & $\begin{array}{l}\text { I group } \\
\text { (n= 30) }\end{array}$ & $\begin{array}{l}\text { II group } \\
(\mathbf{n}=30)\end{array}$ & $\begin{array}{l}\text { Control group } \\
\text { (n= 30) }\end{array}$ \\
\hline Previous labor, total: & $2(6.67)$ & $3(10.00)$ & $10(33.33)$ \\
\hline term & $2(6.67)$ & $2(6.67)$ & $10(3.33)$ \\
\hline preterm & - & $1(3.33)$ & - \\
\hline Miscarriage & $5(16.67)$ & $4(13.33)$ & $2(6.67)$ \\
\hline Missed abortion & $1(3.33)$ & $2(6.67)$ & - \\
\hline Molar pregnancy & - & $1(3.33)$ & - \\
\hline Induced abortion & $3(10.00)$ & $2(6.67)$ & $2(6.67)$ \\
\hline Ectopic pregnancy & $1(3.33)$ & $4(13.33)$ & - \\
\hline
\end{tabular}

IVF. All these patients received progesterone until 20-22 weeks of pregnancy (vaginal micronised progesterone 200-800 mg with tapering of the dose over the second trimester) and were divided into two groups according to the treatment type for $\mathrm{Cl}$. The I group involved 30 women in whom $\mathrm{Cl}$ was corrected only with cervical cerclage or cervical pessary in the second trimester of pregnancy. In 30 persons of the II group, the cervical cerclage or cervical pessary was combined with vaginal micronised progesterone $200 \mathrm{mg}$ ones a day until 34 full weeks of gestation. 30 pregnant women without $\mathrm{Cl}$ or infertility with the physiological course of pregnancy were controls.

The results of randomized clinical trials and metaanalysis performed by R. Romero et al. demonstrated that vaginal progesterone leads to a significant $44 \%$ decrease in preterm birth in high-risk for this entity women with a singleton pregnancy as well as the lower frequency of neonatal mortality and morbidity, and rates of admission to the neonatal intensive care unit at term less than 33 weeks' gestation [12]. In addition, the analysis of the results including 36 randomized controlled trials established the benefits of vaginal progesterone in a reduction in the risk of preterm labor. The use of vaginal progesterone for high-risk women was associated with a significant reduction in the rate of preterm birth at less than 28 and 34 weeks' gestation and in the frequency of infant birth weight less than $2500 \mathrm{~g}$, neonatal death, necrotising enterocolitis and other neonatal morbidities [13]. The results of these and similar studies prompted us to prescribe vaginal progesterone until 34 full weeks of gestation.

$\mathrm{Cl}$ was diagnosed according to transvaginal ultrasound measurements - the uterine cervical length of $25 \mathrm{~mm}$ and less and the cervical funneling progression to a V-shaped funnel by $40 \%$ or more [14]. Infertility was detected on the World Health Organization's recommendations [15]. The diagnosis of placental dysfunction was based on a combination of the results of ultrasound placental parameters (localization, volume, thickness, degree of maturity, presence of infarcts, calcification) and Doppler examination of placental and uterine artery blood flow velocity, presence of fetal growth restriction. The ultrasound examination was carried out with the help of an ultrasound machine Voluson 730 Pro.

Inclusion criteria: singleton pregnancy, $\mathrm{Cl}$, infertility associated with anovulation, written consent to participate from a patient. Exclusion criteria: multiple pregnancy, antiphospholipid syndrome, thrombophilia, pregnancy complicated by ovarian hyperstimulation syndrome, cytogenetic causes of pregnancy loss after IVF, male infertility, connective tissue dysplasia, increased risk for fetal chromosomal abnormalities according to first- or second-trimester genetic screening. The study was carried out in the City Clinical Perinatal Centre (Ivano-Frankivsk, Ukraine) and approved by the Ethics Commission at Ivano-Frankivsk National Medical University (protocol 97/17, 19.10.2017) in accordance with the Declaration of Helsinki.

Maternal serum hormone concentrations were determined by ELISA method using test system kits on an "IMMULITE 2000 Systems Analyzer" (Siemens). We measured the levels of estradiol, progesterone, placental lactogen, prolactin and cortisol at 19-22 and 30-32 weeks' gestation with reagents "IMMULITE 2000 Estradiol", "IMMULITE 2000 Progesterone", "IMMULITE 2000 Placental lactogen", "IMMULITE 2000 Prolactin" and "IMMULITE 2000 Cortisol", respectively. The hormonal levels in the I and II groups were assessed relative to the control group results which were taken as normal indicators in the corresponding gestational age.

The statistical results were calculated in the program Statistica 6.0. The data of the arithmetic mean value, average standard error, criterion $\chi^{2}$ (chi-square test with Yates correction), the nonparametric Mann-Whitney test (to compare two independent groups by a single feature) were used. The difference between the values was considered statistically significant at $P \leq 0.05$.

\section{Results}

The mean age of the patients in the I $(30.67 \pm 0.92$ years old, $\mathrm{P}=0.02)$ and II $(32.17 \pm 0.63$ years, $\mathrm{P}<0.001)$ groups was statistically higher than in the control individuals ( $27.30 \pm 0.92$ years). Equal proportions of women in all groups presented with their first pregnancy $-21(70.00 \%)$ in the I group, $18(60.00 \%)$ - II, and 17 (56.67\%) in the control group; with their second pregnancy - 4 $(13.33 \%), 6(20.00 \%)$ and $8(26.67 \%)$ individuals, respectively, with the third pregnancy $-5(16.67 \%), 6$ (20.00\%) and $5(10.00 \%)$ women, respectively. However, primiparous women predominated among those with $\mathrm{Cl}$ and anovulatory infertility compared to the control subjects. 28 $(93.33 \%)$ patients in the I group were primiparous that was 1.47 times more $\left(X^{2}=6.28, P<0.05\right)$ than in the control group (19 women, $63.33 \%), 27(90.00 \%)$ persons in the II group, 1.42 times more $\left(X^{2}=4.56, P<0.05\right)$ compared to the controls. Multiparous women constituted $2(6.67 \%), 3(10.00 \%)$ and $11(36.67 \%)$ individuals in the I, II and the control groups, respectively. The outcomes of the previous pregnancies are demonstrated in Table 1.

The first half of pregnancy was complicated by threatened spontaneous abortion before 12 weeks of gestation in $18(60.00 \%)$ women in the I group and $23(76.67 \%)$ - in the II, after 12 weeks of gestation - in $18(60.00 \%)$ and 14 $(46.67 \%)$ individuals, respectively. In the control group, 1 (3.33\%) person had early threatened spontaneous abortion, $2(6.67 \%)$ - late threatened spontaneous abortion.

Extragenital diseases were diagnosed more often in the I and II groups compared to the control one. Renal pathology was detected in $5(16.67 \%)$ persons in the I group and $2(6.67 \%)$ - in the II, gastrointestinal pathology -in $8(26.67 \%)$ and $11(36.67 \%)$ women, respectively, overweight and obesity - in 7 (23.33\%) and $9(30.00 \%)$, 
Table 2. The hormone concentration in the examined women

\begin{tabular}{|c|c|c|c|c|c|c|}
\hline \multirow[t]{2}{*}{ Hormone, units } & \multicolumn{2}{|l|}{ I group $(n=30)$} & \multicolumn{2}{|l|}{ II group $(n=30)$} & \multicolumn{2}{|c|}{ Control group $(n=30)$} \\
\hline & 19-22 weeks & $30-32$ weeks & 19-22 weeks & $30-32$ weeks & 19-22 weeks & $30-32$ weeks \\
\hline Estradiol, pg/ml & $9345.67 \pm 207.76$ & $15293.77 \pm 530.97^{\bullet}$ & $9140.57 \pm 343.92$ & $16087.07 \pm 360.25$ & $9826.43 \pm 286.38$ & $16715.07 \pm 305.04$ \\
\hline Progesterone, $\mathrm{ng} / \mathrm{ml}$ & $45.72 \pm 2.95$ & $82.28 \pm 3.79^{\circ}$ & $43.68 \pm 2.53^{*}$ & $95.75 \pm 4.89$ & $52.82 \pm 3.18$ & $106.99 \pm 4.93$ \\
\hline Placental lactogen, mg/L & $2.52 \pm 0.17$ & $6.48 \pm 0.21^{\bullet}$ & $2.55 \pm 0.13$ & $6.81 \pm 0.25$ & $2.86 \pm 0.19$ & $7.26 \pm 0.28$ \\
\hline Prolactin, $\mathrm{ng} / \mathrm{ml}$ & $277.10 \pm 13.70^{\circ}$ & $387.30 \pm 13.36^{\circ}$ & $261.04 \pm 15.72^{*}$ & $339.20 \pm 16.69^{\circ}$ & $162.33 \pm 10.76$ & $273.32 \pm 15.56$ \\
\hline Cortisol, nmol/L & $573.36 \pm 23.07^{\circ}$ & $715.28 \pm 18.26^{\circ}$ & $593.75 \pm 26.83^{\circ}$ & $638.57 \pm 25.93^{\bullet}$ & $409.04 \pm 25.09$ & $561.64 \pm 22.04$ \\
\hline
\end{tabular}

-: significance of the difference in the indicator relative to the control group $(P<0.05)$; *: significance of the difference in the indicator relative to the control group $(P<0.01)$; ${ }^{\circ}$ : significance of the difference in the indicator between the I and II groups $(P<0.01)$.

respectively. Only $1(3.33 \%)$ control person had renal disease, $4(13.33 \%)$ - gastrointestinal pathology and 3 $(10.00 \%)$ - overweight and obesity. It is worth drawing attention to the prevalence of thyroid diseases among the individuals with $\mathrm{Cl}$ and infertility. Pathology of thyroid gland was statistically more often in the I group of patients $(n=9,30.00 \%)$ than that in the control women $(n=1$ $\left.\left(3.33 \% ; X^{2}=5.88, P<0.05\right)\right)$, and $6(20.00 \%)$ persons in the II group were diagnosed with thyroid diseases.

At 19-22 gestational weeks, the maternal serum estradiol concentration in the I and II group patients was slightly lower than that in the control women, but the results were not significant (Table 2). A $13.44 \%$ decrease in progesterone levels was in the I group as compared to the controls and it was more pronounced to $17.30 \%(P<0.05)$ in the II group. The differences in the placental lactogen levels in the women with $\mathrm{Cl}$ and infertility were also insignificant indicating an $11.89 \%$ and $10.84 \%$ decrease relative to the controls. At the same time, a significant increase was estimated regarding the prolactin and cortisol concentrations. The prolactin elevation was $70.70 \%(P<0.001)$ and $60.80 \%(P<0.001)$ in the I and II groups, respectively, compared to the control index. The cortisol concentrations were $40.17 \%(P<0.001)$ and $45.16 \%(P<0.001)$ higher in the I and II group women, respectively, than in the controls.

At 30-32 gestational weeks, we found considerable changes in estradiol and progesterone levels in the patients without adjunct progesterone treatment relative to the physiological index. Indeed, the maternal estradiol concentration was statistically less in the I group $(P<0.05)$ in contrast to the estradiol level in the II group $(P>0.05)$. The analogous situation occurred in the progesterone level. If the maternal progesterone concentration was significantly $17.30 \%$ lower than the control index in the II group at 19-22 gestational weeks, it was slightly $10.51 \%$ ( $P>0.05$ ) lowered at 30-32 gestational weeks. However, this hormone level was markedly decreased by $13.44 \%$ in the I group at the pregnancy period between 19 and 22 weeks and by $23.10 \%(P<0.001)$ at the $30-32$ gestational weeks in comparison with the controls. A similar trend was observed in placental lactogen concentration. At the 30-32 gestational weeks, its level in the II group was around the ranges of the control women. Meanwhile, it was significantly $10.74 \%(P<0.05)$ decreased in the patients of the I group compared to the controls. The dynamics of prolactin in the I group demonstrated its higher level than that in the II and control groups. In the patients with $\mathrm{Cl}$ without progesterone intake, the concentration of this hormone was $41.70 \%(P<0.001)$ greater than that in the control women, whereas the maternal prolactin concentration in the ll group was only $24.10 \%(\mathrm{P}<0.05)$ higher compared to the controls. In addition, this hormone concentration was also statistically significantly different $(P<0.05)$ between the persons of the I and II groups. At 30-32 gestational weeks, the cortisol concentration was higher by $27.36 \%$ $(P<0.001)$ in the persons of the I group, by $13.70 \%(P<$ $0.05)$ - in the II group compared to the physiological index. The maternal cortisol parameters were also significantly different $(P<0.05)$ between women of the two groups.

The role of estradiol during pregnancy is very important. At the beginning of the gestation, it promotes endometrium transformation and implantation of the gestational sac, formation of the chorionic villi. Estradiol also contributes to the formation of blood vessels in the chorionic villi - angiogenesis and vasculogenesis, supports the steroid production, increases the uterine artery blood flow velocity, induces mammary gland for lactation, and increases the uterine activity [16]. The level of estradiol during pregnancy may indicate the development of placental dysfunction [17].

Some researchers demonstrated the elevated levels of prolactin and cortisol in the blood serum of pregnant women after the treatment for infertility with additional reproductive technology [18]. The scientists determined the higher levels of stress, particularly, state and trait anxiety levels in these patients compared to pregnant women who conceived naturally, thus, cortisol and prolactin were considered to be stress-associated hormones.

Among complications in the second half of pregnancy, the threatened preterm labor was diagnosed in 17 (56.67\%) women in the I group and $11(36.67 \%)$ - in the II one, placental dysfunction - in 20 (66.67\%) and $12(40.00 \%)$ individuals, respectively, oligohydramnios - in $5(16.67 \%)$ and $1(3.33 \%)$, polyhydramnios $-7(23.33 \%)$ and 2 (6.67\%), small-for-gestation-age fetus $-7(23.33 \%)$ and $3(10.00 \%)$, respectively, fetal growth restriction - in 3 (10.00\%) women in the I group only. In the control group, 6 (20.00\%) women had placental dysfunction, 2 (6.67 \%) threatened preterm labor, and 1 (3.33\%) -small-for-gestational-age fetus. $23(76.67 \%)$ pregnant women underwent spontaneous labor at term in the I group, $27(90.00 \%)$ - II group, $30(100.00 \%)$ controls; preterm labor $-7(23.33 \%)$ individuals in the I group, $3(10.00 \%)$ - in the II group. The labor was by cesarean section in the majority of women of the I group - $20(66.67 \%)$ and in $14(46.67 \%)$ subjects of the II group, vaginal delivery was in $10(33.33 \%)$ and 16 (53.33\%) persons, respectively, among them 1 (3.33\%) patient in the I group and $2(6.67 \%)$ in the II group had vacuum-assisted vaginal delivery. The main indications for cesarean section in both groups were associated with fetal distress. Fetal distress during pregnancy was an indication for surgery in $11(36.67 \%)$ women in the I group and 4 
$(13.33 \%)-$ in the II, fetal distress during the first period of labor $-9(30.00 \%)$ and $8(26.67 \%)$ persons, respectively; one $(3.33 \%)$ patient in the II group was also operated due to discoordination of contractile uterus activity and one (3.33 \%) - for combined indications (preeclampsia progression, the first pregnancy after the age of 35 years following infertility treatment).

In the control group, only two (6.67\%) pregnancies ended by cesarean section (because of ineffective treatment for decreased uterine contraction strength and fetal distress in the first period of labor), that was $9.99\left(X^{2}=20.74\right.$, $P<0.001)$ and $6.99\left(X^{2}=10.31, P=0.001\right)$ times less than in the I and II groups, respectively. In the control group, $28(93.33 \%)$ patients delivered vaginally.

\section{Discussion}

Preterm birth may be related to bacterial inflammation, decidual bleeding, vascular diseases, decidual senescence, impaired maternofetal immune tolerance, "functional" progesterone withdrawal or overstretching of the myometrium [1]. The most common causes of short cervix are a suspension of progesterone action, congenital short cervix, cervical surgery, $\mathrm{Cl}$, infection, history of a previous preterm birth and others [12].

The management for $\mathrm{Cl}$ patients depends on many factors and includes the timely diagnosis and individual approach. It is considered that surgical correction for $\mathrm{Cl}$ has benefits before 24 weeks of pregnancy with additional indomethacin intake 48 hours prior to the procedure; in diagnosis of $\mathrm{Cl}$ at a later gestational age, a cervical pessary placement with intravaginal micronized progesterone is recommended [19]. Nowadays, there is a discussion about the benefits of vaginal progesterone use versus cervical cerclage in the cases of short cervix [20]. The analysis of 33 pregnant women diagnosed with a short cervix (a mean cervical length of $12.09 \mathrm{~mm}$ ) demonstrated that adjunct vaginal progesterone treatment to cervical cerclage was found to prolong the pregnancy ( 36.36 weeks) compared to the individuals with cervical cerclage alone (32.36 weeks, $P=0.0036)$, and also was associated with higher birth weight $(P=0.0065)[21]$. A group of scientists performed a meta-analysis including 5 trials and 419 women with singleton gestation and a short cervical length and without prior preterm birth that demonstrated the effectiveness of cervical cerclage in the cases of $10 \mathrm{~mm}$ cervical length and less compared to cervical length of $25 \mathrm{~mm}$ [22]. A similar effectiveness of cervical cerclage, cervical pessary or vaginal progesterone was found in women with singleton pregnancy and the history of preterm labor and short cervix in terms of perinatal losses, neonatal morbidity and preterm labor [11]. Investigators of 5 trials comparing vaginal progesterone to placebo ( 265 women) and 5 comparing cerclage to no cerclage (504 women) in patients with a sonographic short cervix [23] concluded that vaginal progesterone and cervical cerclage are equally effective for preventing preterm birth in women with singleton pregnancies diagnosed with a short cervix on second-trimester transvaginal sonography. The similar results demonstrating almost equal efficacy of cervical cerclage, cervical pessary or vaginal progesterone in women with a short cervix were obtained in the multicenter randomized controlled trial [7]. An examination of women with $\mathrm{Cl}$ and a cervical length less than $15 \mathrm{~mm}$, isthmic uterine fibroids and a history of obstetric complications confirmed the benefits of the cervical cerclage and vaginal progesterone treatment, and an intervention by the Arabin cervical pessary insertion reduced the rate of preterm delivery by 1.7 times. A combination of the two methods (cervical cerclage/Arabin pessary with vaginal progesterone adjunctive therapy) in patients at high risk of preterm labor lead to term delivery in $70.4 \%$ of the cases [2].

Insufficient progesterone level was also found in patients with $\mathrm{Cl}$ in the second and third trimesters of pregnancy [24]. Besides that, there are data that progesterone metabolites detected at the late first trimester or early second trimester may serve as markers for delivery prior to 32 weeks [25]. Low maternal progesterone concentration was found to be associated with preterm labor and cervical ripening [12]. Higher levels of maternal serum prolactin and cortisol were observed among patients with disorders of cervical obturation [26] as well as in women after intervention of additional reproductive technology in the first, second and third trimesters of pregnancy [18]. Our results match these data and demonstrate the insufficiency of progesterone in the second trimester in the women with $\mathrm{Cl}$ after IVF as well as higher maternal prolactin and cortisol concentrations in these persons. Both adjunctive micronized progesterone (vaginal or sublingual form) treatment to arginine glutamate before 34-35 weeks and $\mathrm{Cl}$ correction (cervical cerclage/ pessary) in women with $\mathrm{Cl}$ can lead to a decrease in preterm birth rate and placental dysfunction [24]. Our study showed that adjunctive vaginal progesterone treatment to cervical cerclage or pessary in the women with $\mathrm{Cl}$ after IVF increases the progesterone concentration and promotes normalization of prolactin and cortisol in the third trimester of pregnancy. That may lead to lower rate of pregnancy complications associated with progesterone insufficiency and elevated prolactin and cortisol concentrations. We have not found the scientific publications about the detailed mechanisms of vaginal progesterone adjunctive action on the other hormone levels in pregnant women. Nevertheless, it was studied that, for example, placental disorders were associated with deficiency of placental lactogen, which may be an indicator of placental insufficiency [17]. One of the explanations of progesterone significance during pregnancy is related to its anxiolytic and sedative effects resulting in a decrease in stress and anxiety levels in a woman, thus reducing a concentration of stress-associated hormones, including prolactin and cortisol.

\section{Conclusions}

1. There were no significant changes in estradiol, progesterone and placental lactogen concentrations in the second trimester of pregnancy in the women with cervical insufficiency after in vitro fertilization treatment for anovulatory infertility $(P>0.05)$. The levels of these hormones were slightly less than the control indices. However, maternal prolactin (by 60.80-70.70\%) and cortisol levels (by $40.17-45.16 \%$ ) were much higher than the physiological ranges $(P<0.05)$.

2. In patients after in vitro fertilization treatment for anovulatory infertility with adjunctive vaginal progesterone 
treatment to cervical cerclage / pessary for cervical insufficiency, the progesterone level reached the normal indices $(10.51 \%$ less than the physiological ranges, $P>0.05)$ at 30-32 gestational weeks, whereas in women without adjunctive progesterone treatment, this hormone concentration in the third trimester was $23.10 \%(P<0.05)$ decreased compared to the controls. In addition, adjunctive use of vaginal progesterone led to normalization of placental lactogen, lower indices of prolactin and cortisol compared to the women with cervical cerclage / pessary alone.

Prospects for the further research. It seems perspective to perform a detailed analysis of neonatal outcomes in patients with different management strategies in $\mathrm{Cl}$ after IVF treatment for anovulatory infertility.

Conflicts of interest: authors have no conflict of interest to declare. Конфиікт інтересів: віАсутній.

Надійшла Ао реАакції / Received: 20.07.2020

Після Аоопрацювання / Revised: 20.10.2020

Прийнято Ао Аруку / Accepted: 26.10.2020

Information about authors:

Pakharenko L. V., MD, PhD, DSc, Professor of the Department of Obstetrics and Gynecology, Ivano-Frankivsk National Medical University, Ukraine.

ORCID ID: 0000-0003-4774-8326

Perkhulyn O. M., MD, Assistant of the Department of Obstetrics and Gynecology, Ivano-Frankivsk National Medical University, Ukraine.

ORCID ID: 0000-0002-0033-5156

\section{Відомості про авторів:}

Пахаренко $\Lambda$. В., А-р меА. наук, професор каф. акушерства та гінекології, Івано-Франківський національний меАичний університет, Україна.

Перхулин О. М., асистент каф. акушерства та гінекології, ІваноФранківський національний медичний університет, Україна.

\section{Сведения об авторах:}

Пахаренко ^. В., А-р меА. наук, профессор каф. акушерства и гинекологии, Ивано-Франковский национальный медицинский университет, Украина.

Перхулин 0. М., ассистент каф. акушерства и гинекологии, Ивано-Франковский национальный медицинский университет, Украина.

\section{References}

[1] Berger, R., Abele, H., Bahlmann, F., Bedei, I., Doubek, K., Felderhoff-Müser, U., Fluhr, H., Garnier, Y., Grylka-Baeschlin, S., Helmer, H., Herting, E., Hoopmann, M., Hösli, I., Hoyme, U., Jendreizeck, A., Krentel, H., Kuon, R., Lütje, W., Mader, S., Maul, H., ... Surbek, D. (2019). Prevention and Therapy of Preterm Birth. Guideline of the DGGG, OEGGG and SGGG (S2k Level, AWMF Registry Number 015/025, February 2019) - Part 2 with Recommendations on the Tertiary Prevention of Preterm Birth and the Management of Preterm Premature Rupture of Membranes. Geburtshilfe und Frauenheilkunde, 79(8), 813-833. https://doi.org/10.1055/a-0903-2735

[2] Barinov, S. V., Artymuk, N. V., Novikova, O. N., Shamina, I. V., Tirskaya, Y. I., Belinina, A. A., Lazareva, O. V., Kadcyna, T. V., Borisova, A. V., Stepanov, S. S., \& Di Renzo, G. C. (2019). Analysis of risk factors and predictors of pregnancy loss and strategies for the management of cervical insufficiency in pregnant women at a high risk of preterm birth. The Journal of Maternal-Fetal \& Neonatal Medicine, 1-9. https://doi.org/10.1080/14767058.2019.1656195

[3] Cavoretto, P. Candiani, M., Giorgione, V., Inversetti, A., Abu-Saba, M. M., Tiberio, F., Sigismondi, C., \& Farina, A. (2018). Risk of spontaneous preterm birth in singleton pregnancies conceived after IVF/ICSI treatment: meta-analysis of cohort studies. Ultrasound in Obstetrics \& Gynecology, 51(1), 43-53. https://doi.org/10.1002/uog.18930
[4] Brown, R., Gagnon, R., \& Delisle, M. F. (2019). No. 373-Cervical Insufficiency and Cervical Cerclage. Journal of Obstetrics and Gynaecology Canada, 41(2), 233-247. https://doi.org/10.1016/i.jogc.2018.08.009

[5] Trifonova, N. S., Zhukova, E. V., Grineva, A. M., Aleksandrov, L. S. Ishchenko, A. I., Nikonov, A. P., \& Soboleva, V. V. (2017). Klinicheskie osobennosti techeniya beremennosti, rodov i perinatal'nye iskhody u zhenshchin posle ekstrakorporal'nogo oplodotvoreniya s primeneniem donorskikh ovotsitov [Clinical features of the course of pregnancy, labor, delivery, and perinatal outcomes in women after in vitro fertilization using donor oocytes]. Rossiiskii vestnik akushera-ginekologa, 17(1), 46-52. https://doi.org/10.17116/rosakush201717146-52 [in Russian].

[6] Roman, A., Suhag, A., \& Berghella, V. (2016). Overview of Cervical Insufficiency: Diagnosis, Etiologies, and Risk Factors. Clinical Obstetrics and Gynecology, 59(2), 237-240. https://doi.org/10.1097/ GRF.0000000000000184

[7] Hezelgrave, N. L., Watson, H. A., Ridout, A., Diab, F., Seed, P. T., ChinSmith, E., Tribe, R. M., \& Shennan, A. H. (2016). Rationale and design of SuPPoRT: a multi-centre randomised controlled trial to compare three treatments: cervical cerclage, cervical pessary and vaginal progesterone, for the prevention of preterm birth in women who develop a short cervix. BMC Pregnancy and Childbirth, 16(1), Article 358. https://doi. org/10.1186/s12884-016-1148-9

[8] Černohorská, P., Vitásková, H., Kokrdová, Z., Hájek, Z., Koucký, M., \& Pařízek, A. (2019). Cervical cerclage - history and contemporary use. Czech Gynaecology, 84(1), 55-60.

[9] Timofeev, J. (2016). Use of Cervical Pessary in the Management of Cervical Insufficiency. Clinical Obstetrics and Gynecology, 59(2), 311319. https://doi.org/10.1097/GRF.0000000000000196

[10] Boelig, R. C., \& Berghella, V. (2017). Current options for mechanical prevention of preterm birth. Seminars in Perinatology, 41(8), 452-460. https://doi.org/10.1053/j.semperi.2017.08.003

[11] Alfirevic, Z., Owen, J., Carreras Moratonas, E., Sharp, A. N., Szychowski, J. M., \& Goya, M. (2013). Vaginal progesterone, cerclage or cervical pessary for preventing preterm birth in asymptomatic singleton pregnant women with a history of preterm birth and a sonographic short cervix. Ultrasound in Obstetrics \& Gynecology, 41(2), 146-151. https:/l doi.org/10.1002/uog.12300

[12] Romero, R., Yeo, L., Miranda, J., Hassan, S. S., Conde-Agudelo, A. \& Chaiworapongsa, T. (2013). A blueprint for the prevention of preterm birth: vaginal progesterone in women with a short cervix. Journal of Perinatal Medicine, 41(1), 27-44. https://doi.org/10.1515/ipm-2012-0272

[13] Dodd, J. M., Jones, L., Flenady, V., Cincotta, R., \& Crowther, C. A (2013). Prenatal administration of progesterone for preventing preterm birth in women considered to be at risk of preterm birth. Cochrane Database of Systematic Reviews, (7), Article CD004947. https://doi. org/10.1002/14651858.CD004947.pub3

[14] Holianovskyi, O. V., Mekhedko, V. V., Halych, I. D., \& Bachynska, M. A. (2012). Istmiko-tservikalna nedostatnist: suchasni metody korektsil [Cervical insufficiency: modern methods of correction]. Zhinochyi likar, (2), 39-45. [in Ukrainian].

[15] World Health Organization. (2018, February 19). Preterm birth. WHO. https://www.who.int/news-room/fact-sheets/detail/preterm-birth

[16] Dovzhikova, I. V., \& Lutsenko, M. T. (2016). Sovremennye predstavleniya o roli estrogenov vo vremya beremennosti (obzor literatury) [Modern concepts of estrogens role at pregnancy (review)]. Byulleten'fiziologii i patologii dykhaniya, 61, 120-127. https://doi.org/10.12737/21463 [in Russian].

[17] Zhabchenko, I. A., Korniiets, N. H., \& Tertychna-Teliuk, S. V. (2020). Hormonalno-metabolichni osoblyvosti fetoplatsentarnoho kompleksu u vahitnykh-peremishchenykh osib [Hormonal and metabolic features of the placental complex in pregnant women-displaced persons]. Zaporozhye medical journal, 22(1), 79-85. https://doi.org/10.14739/23101210.2020.1.194541 [in Ukrainian].

[18] Vygivska, L. M., Usevych, I. A., Maidannyk, I. V., \& Oleshko, V. F. (2018). Osoblyvosti psykhoemotsiinoho stanu ta bioprodukuvannia stres-asotsiiovanykh hormoniv u vahitnykh pislia zastosuvannia dopomizhnykh reproduktyvnykh tekhnolohii [Features of psychoemotional condition and stress-assosiatate hormons bioproduction in pregnant women after application of assisted reproductive technologies]. Zdorov'e zhenshchiny, (6), 118-121. [in Ukrainian]

[19] Dobrokhotova, Yu. E., Borovkova, E. I., Zalesskaya, S. A., Nagaitseva, E. A., \& Raba, D. P. (2018). Diagnostika i taktika vedeniya patsientok s istmiko-tservikal'noi nedostatochnost'yu [Diagnosis and management patients with cervical insufficiency]. Ginekologiya, 20(2). 41-45. http:// doi.org/10.26442/2079-5696 2018.2.41-45 [in Russian].

[20] Wang, S. W., Ma, L. L., Huang, S., Liang, L., \& Zhang, J. R. (2016). Role of Cervical Cerclage and Vaginal Progesterone in the Treatment of Cervical Incompetence with/without Preterm Birth History. Chinese Medical Journal, 129(22), 2670-2675. https://doi.org/10.4103/0366-6999.193451

[21] Roman, A. R., Da Silva Costa, F., Araujo Júnior, E., \& Sheehan, P. M. (2018). Rescue Adjuvant Vaginal Progesterone May Improve Outcomes in Cervical Cerclage Failure. Geburtshilfe und Frauenheilkunde, 78(8), 785-790. https://doi.org/10.1055/a-0637-9324 
[22] Berghella, V., Ciardulli, A., Rust, O. A., To, M., Otsuki, K., Althuisius, S., Nicolaides, K. H., Roman, A., \& Saccone, G. (2017). Cerclage for sonographic short cervix in singleton gestations without prior spontaneous preterm birth: systematic review and meta-analysis of randomized controlled trials using individual patient-level data. Ultrasound in Obstetrics \& Gynecology, 50(5), 569-577. https://doi.org/10.1002/uog.17457

[23] Conde-Agudelo, A., Romero, R., Da Fonseca, E., O'Brien, J. M. Cetingoz, E., Creasy, G. W., Hassan, S. S., Erez, O., Pacora, P., \& Nicolaides, K. H. (2018). Vaginal progesterone is as effective as cervical cerclage to prevent preterm birth in women with a singleton gestation, previous spontaneous preterm birth, and a short cervix: updated indirect comparison meta-analysis. American Journal of Obstetrics \& Gynecology, 219(1), 10-25. https://doi.org/10.1016/i.ajog.2018.03.028

[24] Zhabchenko, I. A., \& Oleshko, V. F. (2017). Rol hormonalnoho ta obminnoho dysbalansu v rozvytku porushen obturatsiinoi funktsii shyiky matky ta sposoby yoho korektsii [The role of hormonal and metabolic imbalance in the development of impairment of cervix obstructive function and the methods of its correction]. Medychni aspekty zdorovia zhinky, (2), 5-14. [in Ukrainian].

[25] Patil, A. S., Gaikwad, N. W., Grotegut, C. A., Dowden, S. D., \& Haas, D. M. (2020). Alterations in endogenous progesterone metabolism associated with spontaneous very preterm delivery. Human Reproduction Open, 2020(2), Article hoaa007. https://doi.org/10.1093/ hropen/hoaa007

[26] Zhabchenko, I. A., Oleshko, V. F., Bondarenko, O. M., \& Siudmak, O. R. (2016). Osoblyvosti hormonalnoho homeostazu vahitnykh iz funktsionalnym porushenniam obturatsiinoi funktsii shyiky matky [Features of hormonal homeostasis in pregnant women with functional disorders of the cervix obstructive function]. Reproduktyvna endokrynolohiia, (5), 85-89. http://doi.org/10.18370/2309-4117.2016.31.85-89 [in Ukrainian]. 